MINERALOGIA, 48, No 1-4: 87-105 (2017)

DE DE GRUYTER OPEN

DOI: 10.1515/mipo-2017-0015

www.Mineralogia.pl

MineRALOGICAL SOCIETY OF POLAND

Polskie TOWARZYSTWO MINERALOGICZNE

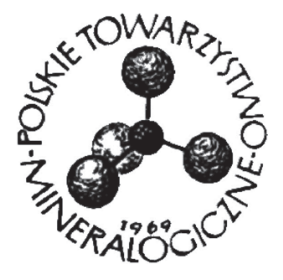

Original paper

\title{
Characteristics of sorbent products obtained by the alkaline activation of waste from waste incineration plants
}

\author{
Agnieszka Grela $^{1 *}$, Michał Łach ${ }^{2}$, Tomasz Bajda ${ }^{3}$, Janusz Mikuła ${ }^{2}$ \\ ${ }^{1}$ Cracow University of Technology, Faculty of Environmental Engineering, Institute of Engineering and Water \\ Management, Warszawska 24, 31-151 Cracow, Poland \\ ${ }^{2}$ Cracow University of Technology, Faculty of Mechanical Engineering, Institute of Materials Engineering, 37 \\ Jana Pawła II Av., 31-864 Cracow, Poland \\ ${ }^{3}$ AGH University of Science and Technology in Cracow, Faculty of Geology, Geophysics and Environmental \\ Protection, Department of Mineralogy, Petrography and Geochemistry, 30 Mickiewicza Av., 30-059 Cracow, \\ Poland \\ * Corresponding author \\ e-mail: agrela@pk.edu.pl
}

Received: April 20, 2017

Received in revised form: August 30, 2017

Accepted: August 30, 2017

Available online: September 30, 2017

\begin{abstract}
In Poland, by 2020 430,000 Mg of hazardous waste will be formed annually by the combustion of waste. This waste must be properly managed so as not to endanger the environment. One promising way to manage selected waste is to process it in the synthesis of materials characterised by sorption properties. The results presented in this paper concern the possibility of producing sorbents from waste materials marked with codes 190112 and 190114, which came from two waste incineration plants in Poland. Alkaline activation was performed using two methods: a) hydrothermal, in a solution of $8 \mathrm{M} \mathrm{NaOH}$ at $75^{\circ} \mathrm{C}$ for $24 \mathrm{~h}$; and b) in an autoclave, using a solution of $2 \mathrm{M} \mathrm{NaOH}$ at $140^{\circ} \mathrm{C}$ for $6 \mathrm{~h}$. XRD analyses led to the identification of materials after synthesis of the following zeolite phases: analcime, chabazite and thomsonite. chabazite and analcime can be valuable absorbent materials.
\end{abstract}

Key-words: alkali-activated, ash and slag from waste incineration 


\section{Introduction}

It is estimated that by 2020 , approximately $430,000 \mathrm{Mg}$ per year of hazardous waste will be produced in Poland (Wielgosiński, Naniecińska 2016). The residues from waste incineration are fly ash and slag, or ash - slag mixtures. It is important to properly manage them so that they do not pose a threat to the environment. The utilisation or the reprocessing of them is entered as part of the principles of the zero-waste economy, the effective use of resources (Resource Efficient Europe) and the closed-loop economy (Circular Economy). The idea of a Circular Economy is an economic model whose objective is to separate economic growth and development from the consumption of resources being depleted. "A circular economy is a systemic solution which relies on giving real priority to secondary raw materials, and even the obligation to use them, before we look to natural resources" (Łącka-Matusiewicz, Fraś 2012).

To correctly select the waste management and neutralisation method, above all its properties should be determined accurately. Most often, the following tests are performed: phase composition characterisation, chemical composition analysis, aqueous leaching testing, fineness and moisture content determination, morphology evaluation, pore size distribution and specific surface area measurements (the Brunauer-Emmett-Taller (BET) and Barrett-Joyner-Halenda (BJH) methods), as well as cation and anion exchange capacity determination ( Each et al. 2016). The results of the studies carried out allow the basic ways of using the waste to be defined.

One promising way to manage waste is to process it in the synthesis of zeolites or other materials, characterised by sorption properties (Charles et al. 2010). Zeolites are crystalline aluminosilicate compounds with a highly developed inner structure (Armbuster, Gunter 2001; Chica 2013) with a characteristic channel structure, in which the channels are interlinked with $\mathrm{SiO}_{4}$ and $\mathrm{AlO}_{4}$ tetrahedra. This makes them very good sorbents, catalysts and ion-exchange materials (Aiello 2002). Due to the high demand of the industry for synthetic zeolites, methods for producing these materials economically are still sought. In recent years, the feasibility of using fly ashes from hard coal and brown coal has been successfully studied (Chang,Shih 1998; Hollman et al. 1999; Inada et al. 2005; Derkowski 2006; Fotovat et al. 2009; Belviso et al. 2010; Franus et al. 2014) as well as ash from fluid boilers (Grela et al. 2016a, Grela et al. 2016b) for the synthesis of zeolite materials. Owing to intense studies, it is possible to discover new zeolite structures and to obtain thorough knowledge of their properties.

Ash from waste incinerators may be used as the starting material for the synthesis of zeolites such as gismondine or gmelite (Yang, Yang 1998; Miyake et al. 2002), zeolite A and zeolite P (Miyake et al. 2002; Tamura et al. 2006; Sallam et al. 2008). It is also possible to obtain zeolite materials from waste incineration slag (Chiang et al. 2012) in this way, e.g. tobermorite and hydrated sodium aluminium silicates were obtained that exhibited the BET specific surface area of $22.1 \mathrm{~m}^{2} \mathrm{~g}^{-1}$ (compared with $4 . \mathrm{m}^{2} \mathrm{~g}^{-1}$ for the starting material). The studies showed the suitability of the materials obtained for the adsorption of heavy metal cations. Zeolites produced from fly ash from waste incineration may be employed for the removal of cadmium, chromium and lead ions (Shim et al. 2003; Gupta et al. 2005; Tao 2006). Other investigations (Rodzewicz et al. 2016) have demonstrated that ash from 
wastewater sludge incineration may be used as a filter filler for the treatment of phosphorus-containing wastewaters.

The aim of this study was to characterise and assess the physicochemical properties of the waste such as slag and ash from waste incineration, and to characterise the synthesis products formed in the autoclaving process.

\section{Materials and methods}

\subsection{Starting materials}

Two waste types with the EWC codes 190112 (bottom ash and slag other than those indicated by code 190111 - P1) and 190114 (fly ash other than those indicated by code 190113 - P2) from two waste incineration plants in Poland were subjected to study. The waste incineration in both the first and in the second plant is carried out in a rotary oven with an after-combustion chamber. Flue gases are cooled down in a recuperator boiler. Table 1 presents the designation of material samples used in this study.

Designations of the materials used in the study.

\begin{tabular}{ll}
\hline Sample & Description \\
\hline P1 & $\begin{array}{l}\text { 190112 - bottom ash and slag other than those indicated by code } 190111 . \\
\text { Industrial and medical waste incineration plant. }\end{array}$ \\
P1A & P1 after synthesis in an autoclave, $\left(2 \mathrm{M} \mathrm{NaOH}, 140^{\circ} \mathrm{C}, 6 \mathrm{~h}\right)$ \\
P1H & P1 after hydrothermal synthesis, $\left(8 \mathrm{M} \mathrm{NaOH}, 75^{\circ} \mathrm{C}, 24 \mathrm{~h}\right)$ \\
P2 & $190114-$ fly ash other than those indicated by code 190113. \\
& The incineration of sewage sludge from waste water treatment plants. \\
P2A & P2 after synthesis in an autoclave, $\left(2 \mathrm{M} \mathrm{NaOH}, 140^{\circ} \mathrm{C}, 6 \mathrm{~h}\right)$ \\
P2H & P1 after hydrothermal synthesis, $\left(8 \mathrm{M} \mathrm{NaOH}, 75^{\circ} \mathrm{C}, 24 \mathrm{~h}\right)$ \\
\hline
\end{tabular}

\subsection{Synthesis}

\subsubsection{Synthesis in autoclave}

The synthesis process was carried out in a PARR pressurised chemical reactor (autoclave). The post-processing waste from the thermal conversion of the waste was denoted as P1 and P2. Bottom ash and slag containing dangerous substances was charged into the reactor with a $250 \mathrm{~g} / 1000 \mathrm{ml} 2 \mathrm{M} \mathrm{NaOH}$ solution added. The mixture thus prepared was closed in the chemical reactor, in which the pressure was increased up to the level of $0.5 \mathrm{MPa}$. After $5 \mathrm{~min}$, the mixture was heated up to $140^{\circ} \mathrm{C}$ at a rate of $2^{\circ} \mathrm{C} / \mathrm{min}$, while the working pressure in the reactor was concurrently raised. The heating time at the reaction temperature was equal to $6 \mathrm{~h}$, and the working pressure was $1.1 \mathrm{MPa}$. After 
heating, the reaction system was cooled down at a rate of $0.3^{\circ} \mathrm{C} / \mathrm{min}$. The total processing time was $24 \mathrm{~h}$ (Fig. 1).

Afterwards, the $\mathrm{NaOH}$ solution used for the synthesis was removed (by decanting the liquid from above the sediment) into an appropriate container. The obtained reaction mixture was placed in a vessel with water warmed up to $30^{\circ} \mathrm{C}$. To wash the mixture, a POLSONIC ultrasonic washer was employed. The washing was carried out for $30 \mathrm{~min}$. After the washings were poured out, the reaction mixture was washed with water until the $\mathrm{pH}$ of the washings fell below 9. Subsequently, the reaction mixture was dried at a temperature of $100^{\circ} \mathrm{C}$ for $12 \mathrm{~h}$.

\subsubsection{Hydrothermal synthesis}

The respective measured amounts of waste P1 and P2 were suffused with $8 \mathrm{M} \mathrm{NaOH}$ solution and placed in polypropylene cylindrical vessels with a capacity of $1000 \mathrm{ml}$. The containers were sealed and placed in a drying oven at $75^{\circ} \mathrm{C}$ for $24 \mathrm{~h}$. After $24 \mathrm{~h}$, the final reaction mixture was cooled to room temperature and rinsed using the procedure described above (synthesis in autoclave).

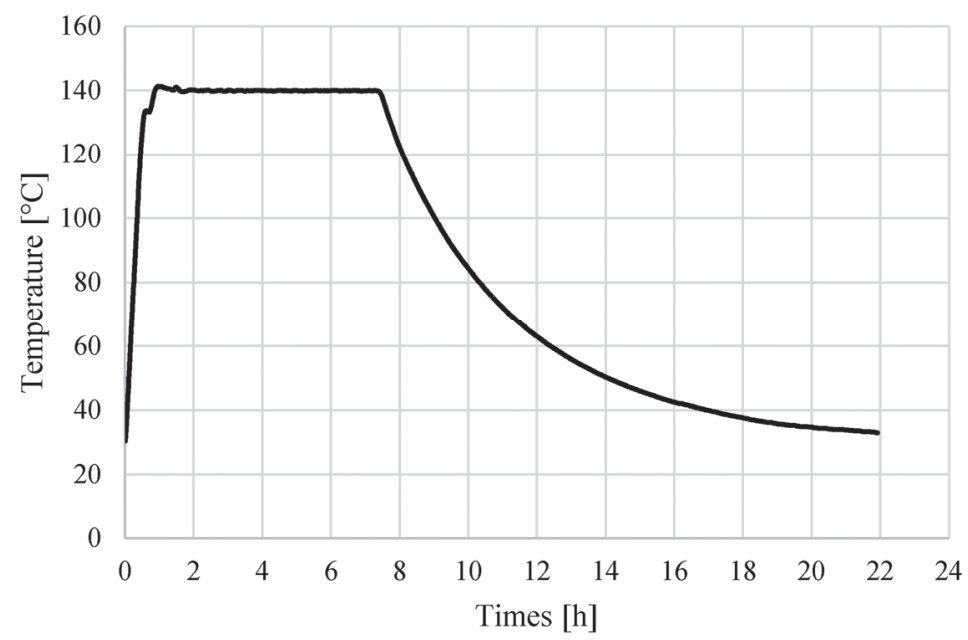

Fig. 1. Schematic diagram of the zeolite production process by autoclaving.

\subsection{Examination methods}

The phase composition of the samples - P1, P1A, P1N, P2, P2A and P2N - was determined using the powder X-ray diffraction (XRD) Debye-Scherrer-Hull method. Diffractograms of the samples were recorded with the use of a RigakuSmartLab X-ray diffractometer using the following parameters: $\mathrm{CuK} \alpha$ radiation, a graphite reflection monochromator, tube voltage $45 \mathrm{kV}$, tube current 200 , step size $2 \theta=0.05^{\circ}$. The values of the interplanar distances were used for the identification of phases present in the samples 
based on data contained in the International Centre for Diffraction Data (ICDD 2014) catalogue and XRAYAN software. For samples P1 and P2, their chemical composition was determined. The analyses were carried out using a XRF WDX PANalytical spectrometer.

The dioxin content was determined with gas chromatography coupled with mass spectrometry (GC-MS/MS) in the Laboratory of Trace Analysis at the Cracow University of Technology. The examination was carried out according to the $\mathrm{P} / 01 / 03$ procedure imposed on $11^{\text {th }}$ March 2010. The results were expressed as the upper limit of toxic equivalency (TEQ) according to I-TEF (1988).

Aqueous leaching tests were performed in the Mo-BRUK S.A. accredited laboratory in accordance with PN-EN 12457-4:2006. Samples for the determination of metal content were prepared according to PN-EN ISO 15587-2:2005, depending on the type of substance analysed, and according to the stander code: gravimetry, spectrophotometry, ionchromatography, or Inductively Coupled Plasma - Optical Emission Spectrometry (ICPOES). The masses of the analysed samples were of ca. $2.5 \mathrm{~kg}$ each. Single-stages were, batch test, at a liquid to solid phase ratio of $101 \mathrm{~kg}^{-1}$ in the case of below $10 \mathrm{~mm}$ grain-size materials (without size reduction or with size reduction).

Fineness testing was carried out in accordance with EN 451-2 by wet sieving. Moisture content was determined in the delivered conditions by an analytical method of drying the ash in a moisture analyser to constant mass.

The morphology of samples was studied with a JEOL JSM-820 Scanning Electron Microscope (SEM). Samples were appropriately prepared beforehand. Small quantities of materials were dried to constant mass, and then were placed on a carbon substrate that ensured removal of the charge from the sample. The materials were coated with a thin layer of gold by a JEOL JEE-4X Vacuum Evaporator.

Porosity and specific surface area measurements were performed with the use of a BETASAP 2020 Accelerated Surface Area and Porosimetry Analyser. Samples were degassed at a temperature of $373 \mathrm{~K}$ for $24 \mathrm{~h}$. To determine the distribution of pore volume function in the materials analysed, experimental low-temperature $(77 \mathrm{~K})$ nitrogen adsorption isotherms were used. The Barrett-Joyner-Halenda method was employed, and to determine the specific surface area, the Brunauer-Emmett-Taller method was applied.

The Cation Exchange Capacity (CEC) was determined with the $\mathrm{NH}_{4}$ sorptiondesorption method, while the Anion Exchange Capacity (AEC) was determined with the phosphate method (Grela, Bajda 2017).

\section{Results and discussion}

\subsection{Raw materials}

Figures $2 \mathrm{a}$ and $2 \mathrm{~b}$ present the recorded diffractograms of the waste samples, P1 and P2, respectively. Based on the analysis of the diffraction spectrum it was found that in sample P1 the following phases are present: quartz, perovskite, ilmenite, rutile, esseneite, olivine, feldspars, and other calcium and magnesium silicates, such as $\mathrm{Ca}_{2} \mathrm{Mg}_{6} \mathrm{Si}_{6} \mathrm{O}_{20}$ (Fig. 2a); while in sample $\mathrm{P} 2$, the following phases were identified: quartz, calcium and aluminium phosphates, anhydrite, plagioclase, and wüstite (Fig. 1b). 
a)

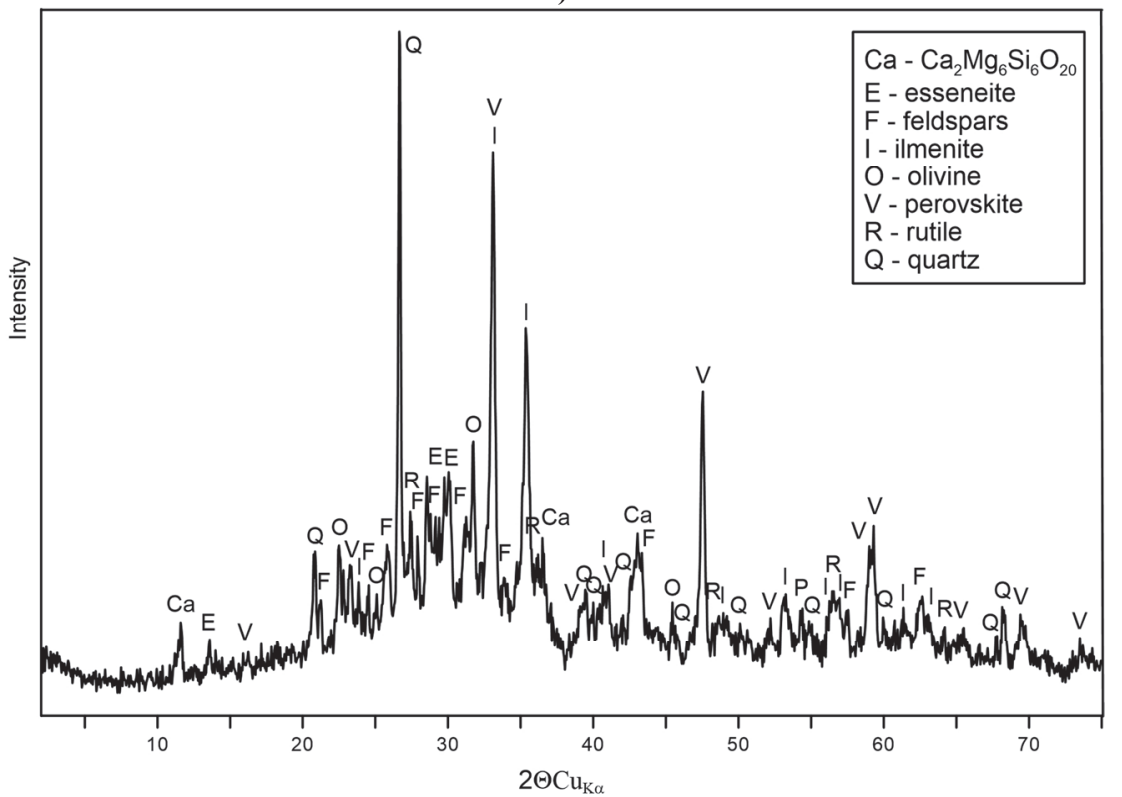

b)

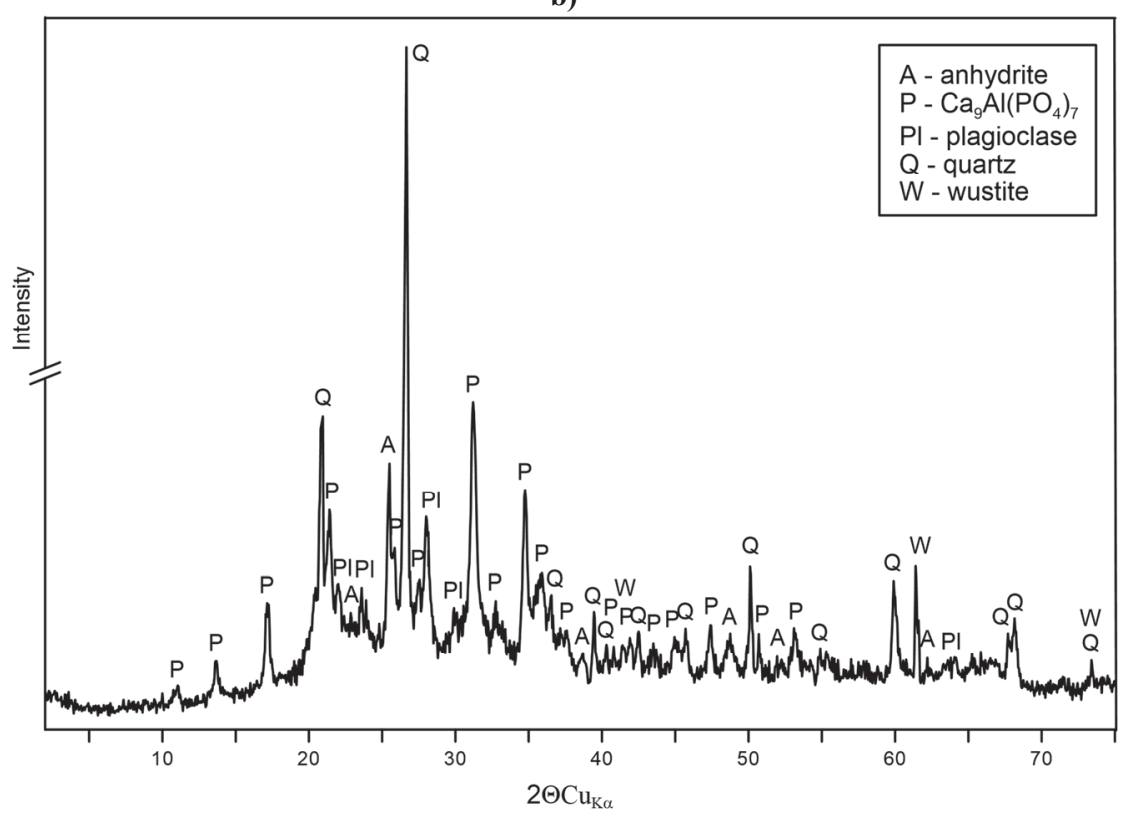

Fig. 2. X-ray diffraction pattern of samples: $\mathrm{P} 1$ (a): $\mathrm{Ca}_{2} \mathrm{Mg}_{6} \mathrm{Si}_{6} \mathrm{O}_{20}$ PDF-2 No. 02-0558, Esseneite PDF-2 No. 25-0143, Feldspars PDF-2 No. 20-0572, Ilmenite PDF-2 No. 29-0733, Olivine PDF-2 No. 07-0164, Perovskite PDF-2 No. 42-0423, Rutile PDF-2 No. 34-0180,

Quartz PDF-2 No. 05-0490; and P2 (b): Anhydrite PDF-2 No. 06-0226, Ca $\mathrm{Al}_{(}\left(\mathrm{PO}_{4}\right)_{7}$ PDF-2 No. 481192, Plagioclase PDF-2 No. 41-1486, Quartz PDF-2 No. 05-0490, Wüstite PDF-2 No. 461312. 
Table 2 presents the chemical composition analysis results for the waste samples. The dominating components are $\mathrm{SiO}_{2}$ and $\mathrm{Al}_{2} \mathrm{O}_{3}$, which are considered to play a key role in zeolite formation. $\mathrm{CaO}$ (ca. 16wt\%) adversely affects the process of zeolite phase formation. The content of $\mathrm{SiO}_{2}$ and $\mathrm{Al}_{2} \mathrm{O}_{3}$ is higher in $\mathrm{P} 2$ (approx. 45\%) in comparison with sample (P2), which contains $29 \%$.

The analyses carried out of the dioxin content showed a total content of dioxins $(\mathrm{I}-\mathrm{PCDD} / \mathrm{F}-\mathrm{TEQ})\left(\mathrm{ng} \mathrm{g}^{-1}\right): \mathrm{P} 1=0.30 \pm 0.078$ and P2 $=0.0092 \pm 0.0024$.

The result is expressed as standardised TEQ according to the I-TEF of 1988 and presented as its upper limit. The total dioxin content of $\mathrm{P} 1$ is almost thirty-two times higher than in P2.

Despite such differences, the dioxin content of both wastes is at a low level. In Poland, there are no regulations concerning dioxin and furan emissions from waste incineration, and their content in ashes and slags is not routinely determined.

TABLE. 2

The chemical composition (wt\%) of samples P1 and P2 used in the study.

\begin{tabular}{lllllllllllll}
\hline Sample & $\mathrm{SO}_{3}$ & $\mathrm{P}_{2} \mathrm{O}_{5}$ & $\mathrm{SiO}_{2}$ & $\mathrm{TiO}_{2}$ & $\mathrm{Al}_{2} \mathrm{O}_{3}$ & $\mathrm{Fe}_{2} \mathrm{O}_{3}$ & $\mathrm{Na}_{2} \mathrm{O}$ & $\mathrm{K}_{2} \mathrm{O}$ & $\mathrm{CaO}$ & $\mathrm{MgO}$ & $\mathrm{Cl}$ & $\mathrm{Br}$ \\
\hline $\mathrm{P} 1$ & 4.29 & 1.48 & 18.67 & 10.52 & 10.27 & 16.94 & 3.45 & 0.36 & 15.54 & 2.35 & 1.88 & 0.02 \\
$\mathrm{P} 2$ & 2.75 & 21.69 & 20.04 & 0.71 & 24.84 & 5.15 & 1.01 & 1.11 & 16.09 & 2.84 & 0.03 & 0.00 \\
\hline
\end{tabular}

Setting out dioxin emission standards would result in the necessity of carrying out appropriate controls. Dioxin emission testing is very costly and only a few research centres in Poland are able to take on the task of determining the dioxin concentration (Pająk 1996).

The toxicity of the ash and slag may be compared with the pollution limit values that are used for the ground or soil. A total dioxin content less than $0.005 \mathrm{ng} \mathrm{g}^{-1}$ allows the area to be used for agricultural purposes without any limitations. If the total dioxin content is in the range of $0.04-0.1 \mathrm{ng} \mathrm{g}^{-1}$, then it is permitted to use the area for fruit and shrub growing (albeit with dioxin content control of other products), as well as for recreation grounds for children. A total dioxin content in the range of $0.1-1.0 \mathrm{ng} \mathrm{g}^{-1}$ results in the total unsuitability of the material for use in agriculture and horticulture, and it must be replaced (Pająk 1996).

Table 3 presents the results of the aqueous leaching tests for P1 and P2. Based on the results obtained, it was concluded that high amount of molybdenum and sulphate ions are washed. Sample P1 contains an elevated amount of chloride ions. The elution of total dissolved solids (TDS) is twice as high for P1 (29.05 mg kg-1) compared to P2 (14.38 $\mathrm{mg} \mathrm{kg}^{-1}$ ). Samples $\mathrm{P} 1$ and $\mathrm{P} 2$ have a similar $\mathrm{pH}$ in the range of 9.4.

Table 4 shows selected physical properties of the waste samples. The test results are significant for their technological importance. They affect the alkaline activation process with respect to their water demand. Water demand depends on the moisture content level and their grain size (fineness). The drier as well as the smaller the grains, the higher the absorptivity of the liquid alkaline activator. It was found that the studied waste samples differed slightly in their fineness, meant as the sieve residue (aperture size $0.045 \mu \mathrm{m}$ ) at wet 
sieving. The results obtained show that the particle or grain size distribution of the tested waste samples are small.

Figures 3 shows the morphology of the waste samples. In both samples, the irregular shape of the grains and size variation can be observed. At high magnification, in sample P1 a plumose surface is partially visible, while in sample P2 the grains are smooth. Shapes of rods and blades can also be observed. In both cases, the grains of the waste often form agglomeration.

Leaching tests results of samples $\mathrm{P} 1$ and $\mathrm{P} 2\left(\mathrm{mg} \mathrm{kg}^{-1}\right)$.

\begin{tabular}{|c|c|c|c|c|}
\hline \multirow{2}{*}{ 1) 2) } & \multicolumn{2}{|c|}{$\begin{array}{l}\text { Permissible leaching limit values }{ }^{1)} \\
\text { Liquid/solid phase }=101 / \mathrm{kg}[\mathrm{mg} / \mathrm{kg} \text { dry substance }]\end{array}$} & \multirow{2}{*}{$\begin{array}{l}190112 \\
\text { P1 }\end{array}$} & \multirow{2}{*}{$\begin{array}{l}190114 \\
\text { P2 }\end{array}$} \\
\hline & $\begin{array}{l}\text { Criteria for the acceptance of the } \\
\text { waste to be deposited at an inert } \\
\text { waste landfill }\end{array}$ & $\begin{array}{l}\text { Criteria for the acceptance of } \\
\text { the waste to be deposited at a } \\
\text { hazardous waste landfill }\end{array}$ & & \\
\hline As & 0.5 & 25 & $<0.5$ & $<0.5$ \\
\hline $\mathrm{Ba}$ & 20 & 300 & 1.59 & 0.80 \\
\hline $\mathrm{Cd}$ & 0.04 & 5 & $<1$ & $<1$ \\
\hline $\mathrm{Cr}$ & 0.5 & 70 & 1.59 & $<1$ \\
\hline $\mathrm{Cu}$ & 2 & 100 & $<1$ & $<1$ \\
\hline $\mathrm{Hg}$ & 0.01 & 2 & $<0.001$ & $<0.001$ \\
\hline Mo & 0.5 & 30 & 10.73 & 4.87 \\
\hline $\mathrm{Ni}$ & 0.4 & 40 & $<1$ & $<1$ \\
\hline $\mathrm{Pb}$ & 0.5 & 50 & $<1$ & $<1$ \\
\hline $\mathrm{Sb}$ & 0.06 & 5 & $<0.5$ & $<0.5$ \\
\hline $\mathrm{Se}$ & 0.1 & 7 & $<0.5$ & $<0.5$ \\
\hline $\mathrm{Zn}$ & 4 & 200 & $<1$ & $<1$ \\
\hline $\mathrm{Cl}^{-}$ & 800 & 25000 & 7737.4 & $<250$ \\
\hline $\mathrm{F}^{-}$ & 10 & 500 & 7.52 & 52.2 \\
\hline $\mathrm{SO}_{4}^{2-}$ & 1000 & 50000 & 7511.2 & 8313 \\
\hline DOC & 500 & 1000 & $<300$ & $<300$ \\
\hline $\left.\operatorname{TDS}^{* *}\right)$ & 4000 & 100000 & 29050 & 14380 \\
\hline $\mathrm{Cr}^{6+}$ & & & $<0.5$ & $<0.5$ \\
\hline $\mathrm{pH}$ & & & 9.3 & 9.4 \\
\hline
\end{tabular}

1) Permissible leaching limit values in the case of waste deposited at a landfill provided with leachate collection systems directed afterwards to the wastewater treatment plant, with the exception of DOC and TDS, are regarded as fulfilled in the case of values higher than set out in the Table.

${ }^{2)}$ Values for TDS may be used interchangeably for sulphates and chlorides. 

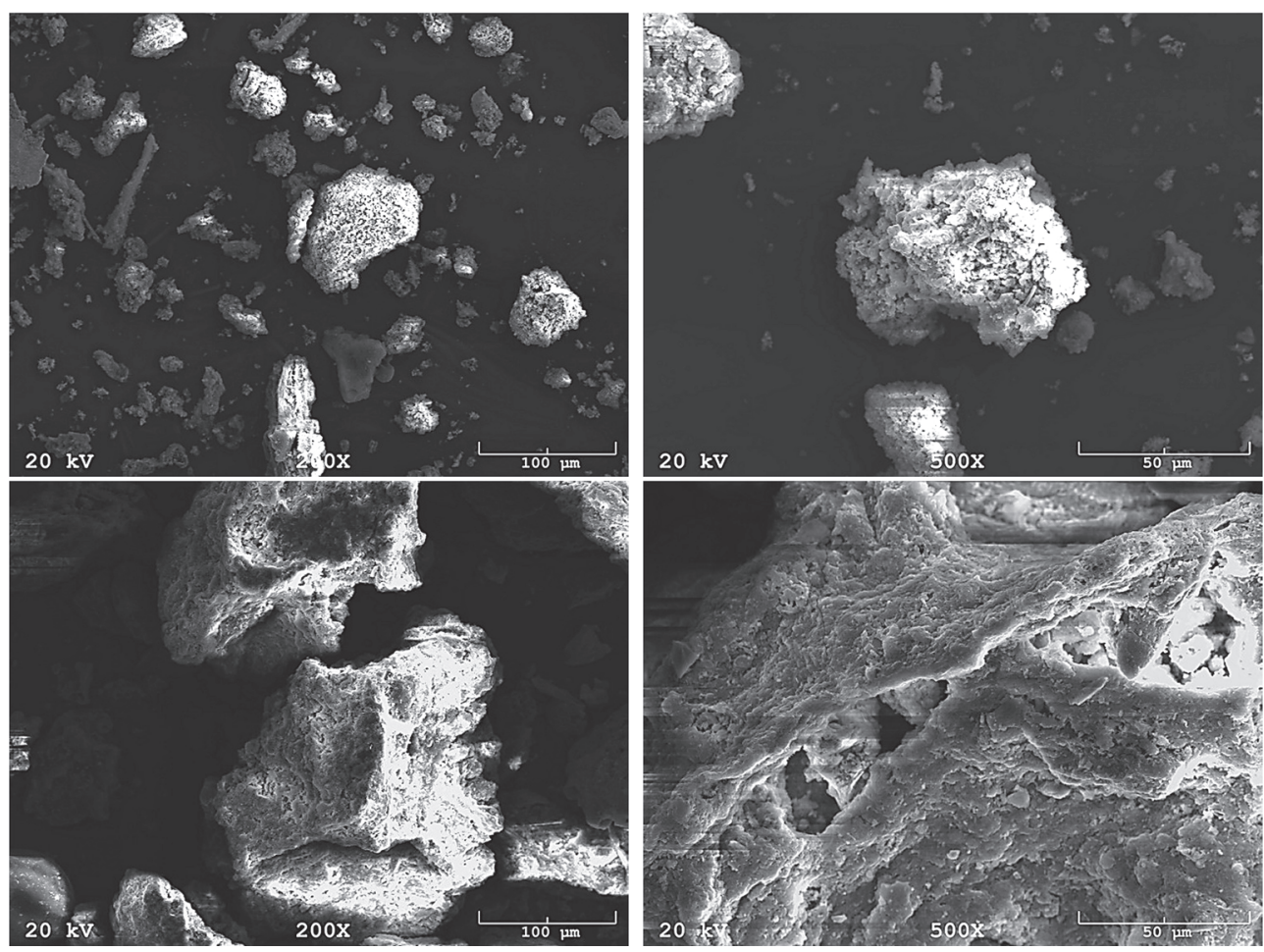

Fig. 3. SEM images of samples P1(a, b) and P2 (c, d).

TABLE 4

Textural testing results and CEC and AEC results for samples $\mathrm{P} 1$ and $\mathrm{P} 2$, and the results of the physical properties' testing of samples $\mathrm{P} 1$ and $\mathrm{P} 2$.

\begin{tabular}{|c|c|c|c|c|c|c|c|c|c|}
\hline Sample & $\begin{array}{l}\mathrm{BET} \\
{\left[\mathrm{m}^{2} / \mathrm{g}\right]}\end{array}$ & $\begin{array}{l}\mathrm{BJH} \\
{\left[\mathrm{m}^{2} / \mathrm{g}\right]}\end{array}$ & $\begin{array}{l}\text { Single } \\
\text { point } \\
\text { adsorption } \\
{\left[\mathrm{cm}^{3} / \mathrm{g}\right]}\end{array}$ & $\begin{array}{l}\text { Adsorption } \\
\text { average } \\
{[\mathrm{nm}]}\end{array}$ & 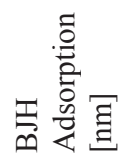 & 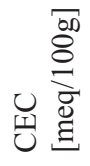 & 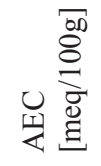 & $\begin{array}{l}\text { Fineness } \\
{[\%]}\end{array}$ & $\begin{array}{l}\text { Moisture } \\
{[\%]}\end{array}$ \\
\hline P1 & 20.85 & 16.35 & 0.035 & 6.80 & 8.63 & 5.58 & 34.07 & $\begin{array}{l}87.88 \pm \\
1.33\end{array}$ & $\begin{array}{l}7.58 \pm \\
0.09\end{array}$ \\
\hline P2 & 4.51 & 2.62 & 0.012 & 10.40 & 17.26 & 3.31 & 24.46 & $\begin{array}{l}65.44 \pm \\
0.70\end{array}$ & $\begin{array}{l}0.23 \pm \\
0.01\end{array}$ \\
\hline
\end{tabular}

The textural parameters were determined for samples P1 and P2 (Table 4). Sample P1 has a type II isotherm, while sample P2 has a type III isotherm, but both have a hysteresis loop of type H3 (Fig. 4). This corresponds to a mesoporous character with the formation of slit-shaped pores arising from the stacking of crystal particles. The specific surface area values (SBET) of samples P1 and P2 were $20.85 \mathrm{~m}^{2} \mathrm{~g}^{-1}$ and $4.51 \mathrm{~m}^{2} \mathrm{~g}^{-1}$, respectively. The total pore volume values were $0.035 \mathrm{~cm}^{3} \mathrm{~g}^{-1}$ and $0.012 \mathrm{~cm}^{3} \mathrm{~g}^{-1}$, respectively (Table 4). 
a)

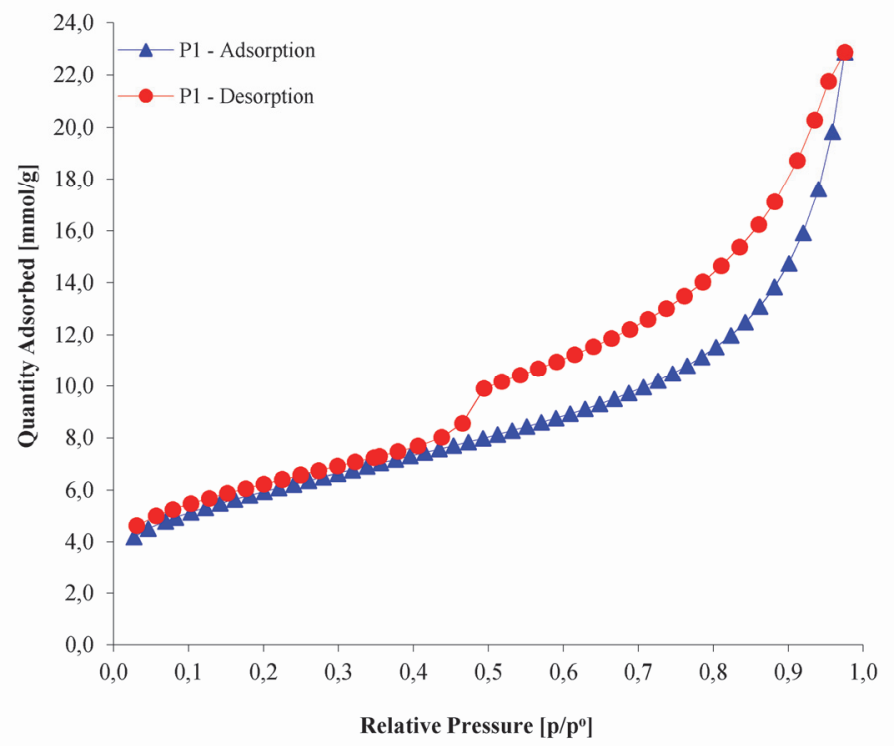

b)

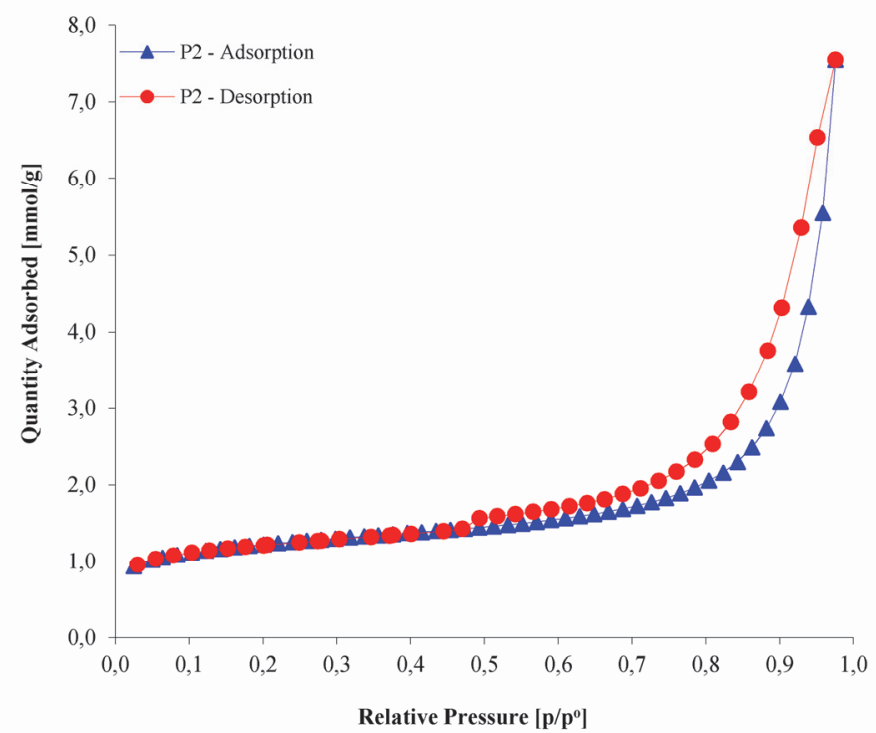

Fig. 4. BET adsorption and desorption isotherms: (a) P1, (b) P2.

The determined CEC and AEC values for samples P1 and P2 are listed in Table 4. The higher the ion-exchange capacity material, the higher the quantity of anions or cations retained on the material by the ion-exchange process. Comparing both samples, it can be determined that they have a much greater capacity for anion than cation exchange. Sample 
P1 has a six times larger AEC than CEC. For sample P2, the AEC is eight times larger than the CEC.

\subsection{Materials after synthesis}

Figures 5a and 5b demonstrate the diffractograms of samples P1A (a) and P1H (b). XRD analysis allowed identification of the following in the studied materials. In sample P1A, quartz, perovskite, ilmenite, rutile and esseneite all occur in the starting material and the product of synthesis; chabazite from the zeolite groups; tobermorite, an alteration product of calcium minerals occurring in the substrate of synthesis; and hydrous sodium and titanium silicates, the product of the reaction between $\mathrm{NaOH}$ and Ti minerals. Whereas in sample $\mathrm{P} 1 \mathrm{H}$, the following phases are present: quartz, perovskite, ilmenite, rutile and unreacted reagents occurring in the starting samples; chabazite and thomsonite from the zeolite group; and tobermorite and hydrous sodium and titanium silicates.

Figures $6 \mathrm{a}$ and $6 \mathrm{~b}$ present the recorded diffractograms of samples $\mathrm{P} 2 \mathrm{~A}$ and $\mathrm{P} 2 \mathrm{H}$, respectively, after hydrothermal synthesis. Based on the analysis of the diffraction spectrum, sample P2A contains two zeolites phases: analcime and thomsonite, and quartz as unreacted phase residue remaining in the matrix from the starting material. In sample $\mathrm{P} 2 \mathrm{H}$, the following phases were identified: unreacted quartz, zeolites phases or from the analcime and thomsonite group, and hydroxyapatite, a product of the transformation of initial phosphorous and calcium minerals in the presence of $\mathrm{NaOH}$.

Synthetic zeolites (e.g. chabazite and analcime) obtained by the transformations of P1 and $\mathrm{P} 2$ can be a valuable absorbent material for the gaseous forms of $\mathrm{NH}_{3}$ and $\mathrm{Hg}$, as well as $\mathrm{CO}_{2}$ and $\mathrm{SO}_{2}$ (Morency et al. 2002; Querol et al. 2002; Wdowin et al. 2012; Wdowin et al. 2014).

Figure 7 presents the morphology of the products obtained by alkali activation of the tested waste. There is a clear change in the morphological forms of the materials in comparison with the starting materials. In the case of sample $\mathrm{P} 1 \mathrm{H}$, a slightly feathered structure can be observed, the grains are made up of rods, and in most parts of interconnected plaques. These are structures with appearance characteristic of tobermorite and chabazite. Sample P1A has quite a different structure, the grains of which consist of hexagonal rods. Samples P2A and P2H consist of grains of spherical-surface-like structures, where stamens and plaques have crystallised.

Samples P1A and P1H show a similar type of isotherm and hysteresis loop of type H3, as in the case of the initial samples. However, we observed a relatively higher increase in the SBET value for sample P1 synthesised using the autoclave method $\left(51.49 \mathrm{~m}^{2} \mathrm{~g}^{-1}\right)$ than in the case of the hydrothermal method $\left(37.09 \mathrm{~m}^{2} \mathrm{~g}^{-1}\right)$. Interestingly, the total pore volume is higher for sample P1H $\left(0.113 \mathrm{~cm}^{3} \mathrm{~g}^{-1}\right)$ than for P1A $\left(0.071 \mathrm{~cm}^{3} \mathrm{~g}^{-1}\right)$. Samples P2A and P2H have similar SBET values $\left(43.30 \mathrm{~m}^{2} \mathrm{~g}^{-1}\right.$ and $46.26 \mathrm{~m}^{2} \mathrm{~g}^{-1}$, respectively), but the total pore volume of sample P2A $\left(0.114 \mathrm{~cm}^{3} \mathrm{~g}^{-1}\right)$ is nearly twice the value of sample $\mathrm{P} 2 \mathrm{H}(0.056$ $\left.\mathrm{cm}^{3} \mathrm{~g}^{-1}\right)$ (Table 6). This indicates that the synthesis method had a significant influence on the textural parameters. (Table 6). 
a)

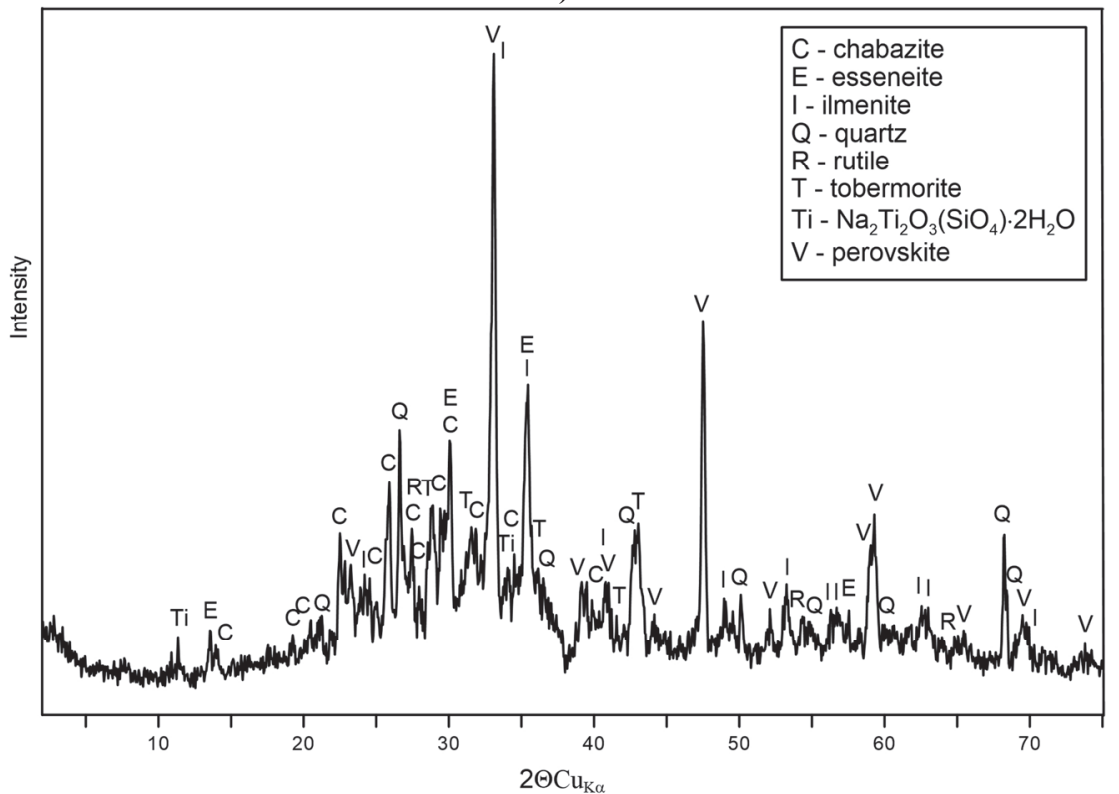

b)

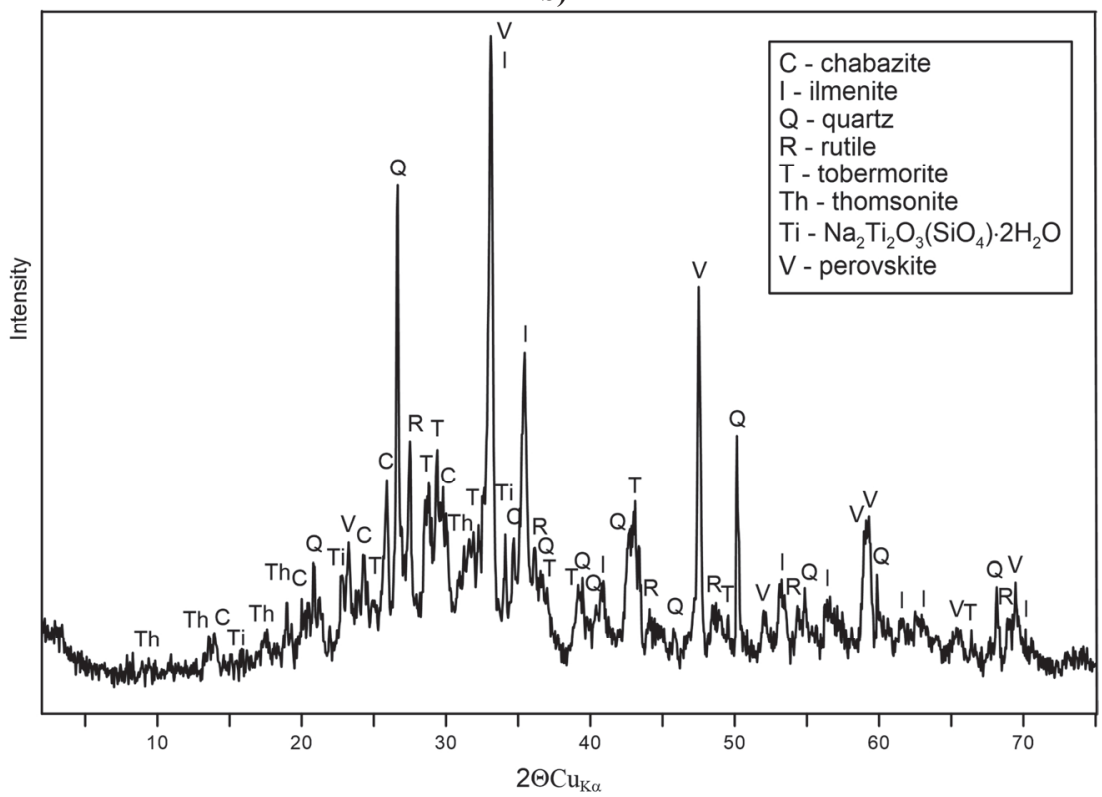

Fig. 5. X-ray diffraction pattern of samples. P1A (a): Chabazite PDF-2 No. 44-0248, Esseneite PDF-2 No. 25-0143, Ilmenite PDF-2 No. 29-0733, Quartz PDF-2 No. 05-0490, Rutile PDF-2 No. 34-0180, Tobermorite PDF-2 No. 10-0374, $\mathrm{Na}_{2} \mathrm{Ti}_{2} \mathrm{O}_{3}\left(\mathrm{SiO}_{4}\right) \cdot 2 \mathrm{H}_{2} \mathrm{O}$ PDF-2 No. 47-0591, Perovskite PDF-2 No. 42-0423; and P1H (b): Chabazite PDF-2 No. 44-0248, Ilmenite PDF-2 No. 29-0733, Quartz PDF-2 No. 05-0490, Rutile PDF-2 No. 34-0180, Tobermorite PDF-2 No. 10-0374, Thomsonite PDF No. 461448, $\mathrm{Na}_{2} \mathrm{Ti}_{2} \mathrm{O}_{3}\left(\mathrm{SiO}_{4}\right) \cdot 2 \mathrm{H}_{2} \mathrm{O}$ PDF-2 No. 47-0591, Perovskite PDF-2 No. 42-0423. 
a)

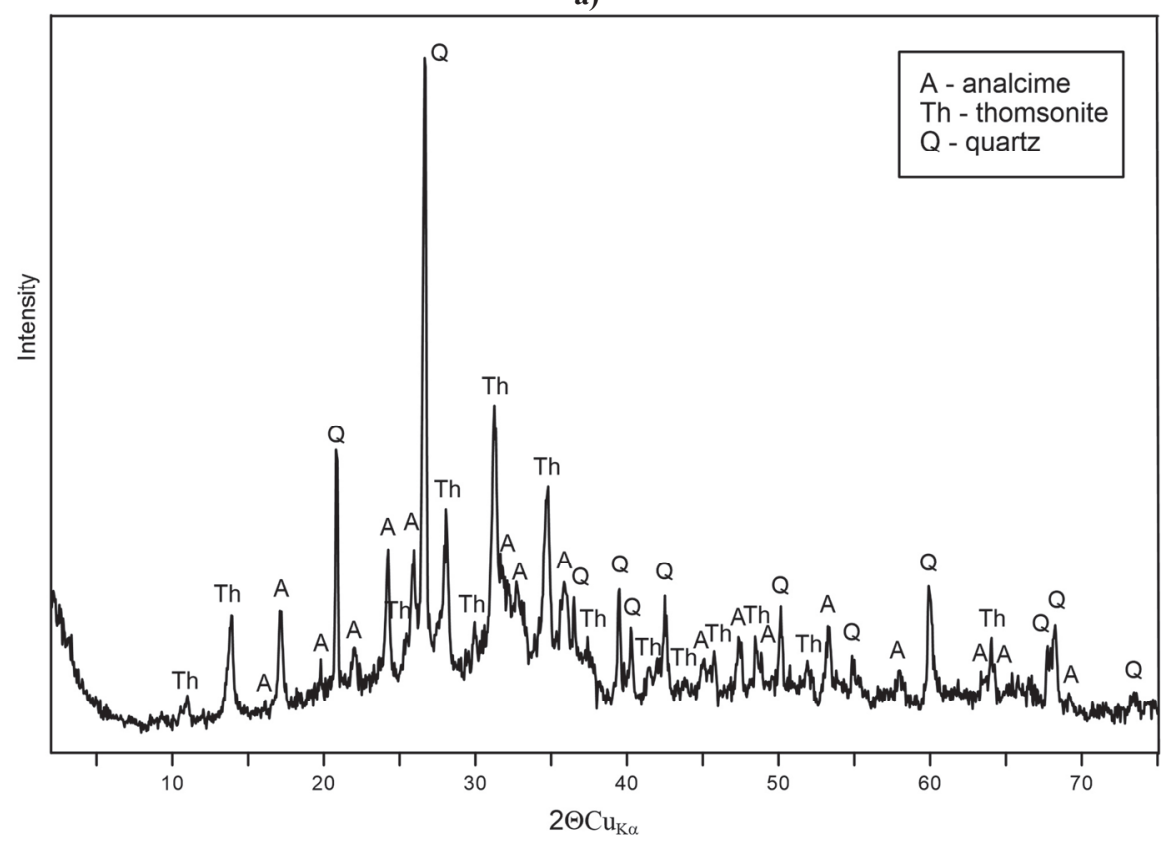

b)

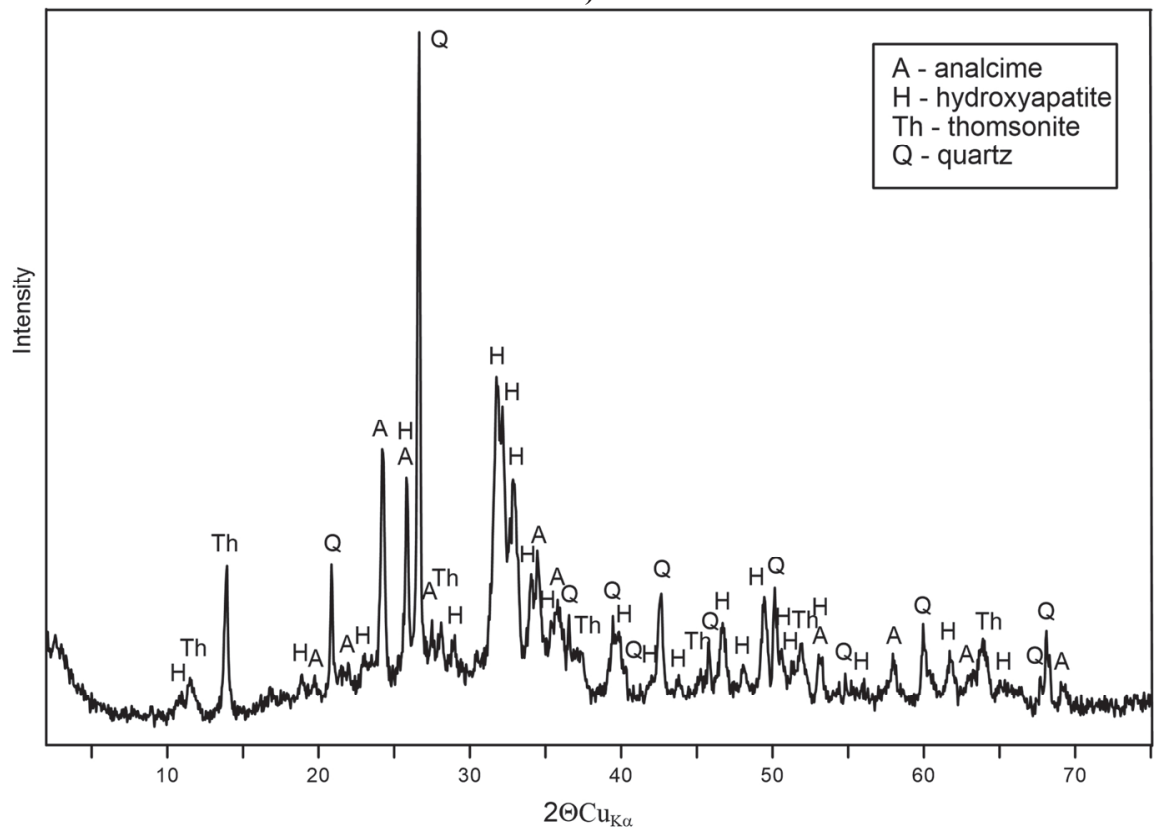

Fig. 6. X-ray diffraction pattern of samples. P2A(a): Analcime PDF No. 07-0364, Thomsonite PDF No. 46-1448, Quartz PDF No. 05-0490; and P2H (b): Analcime PDF No. 07-0364, Hydroxyapatite PDF No. 24-0033, Thomsonite PDF No. 46-1448, Quartz PDF No. 05-0490. 
a)

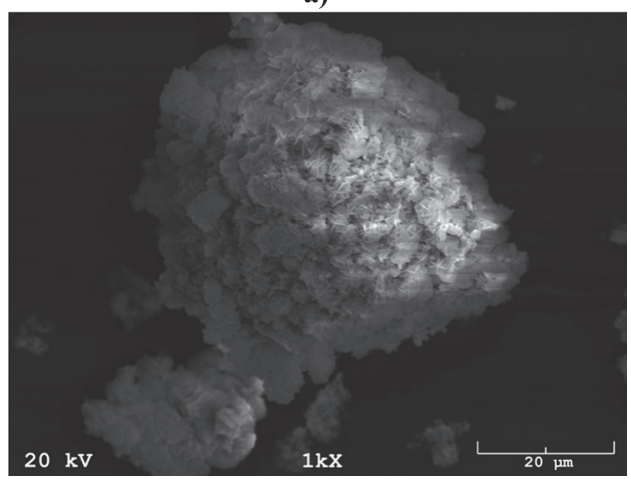

c)

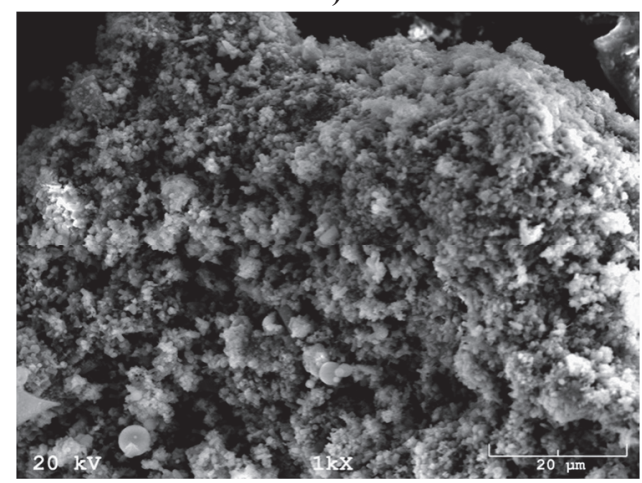

e)

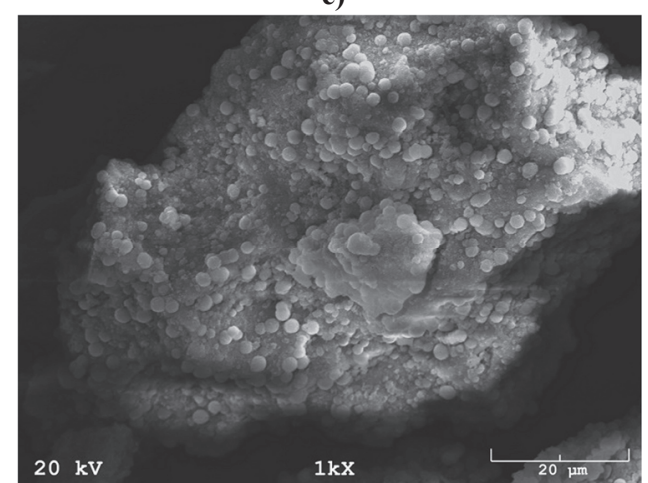

$1 \mathrm{kx}$ b)

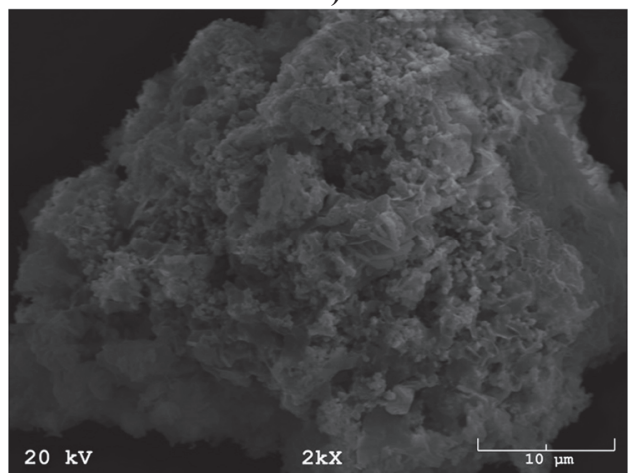

d)

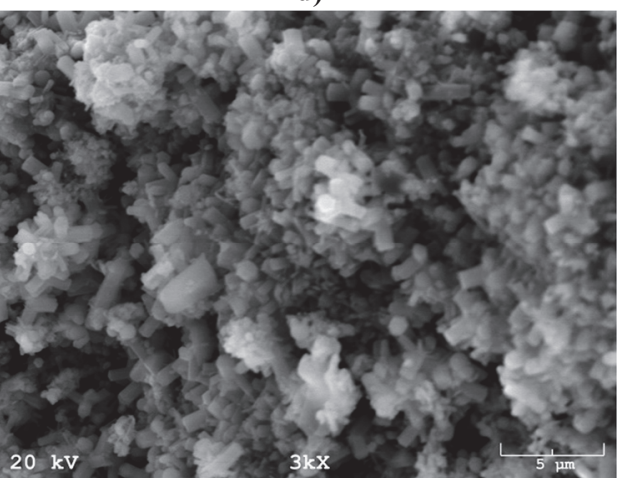

f)

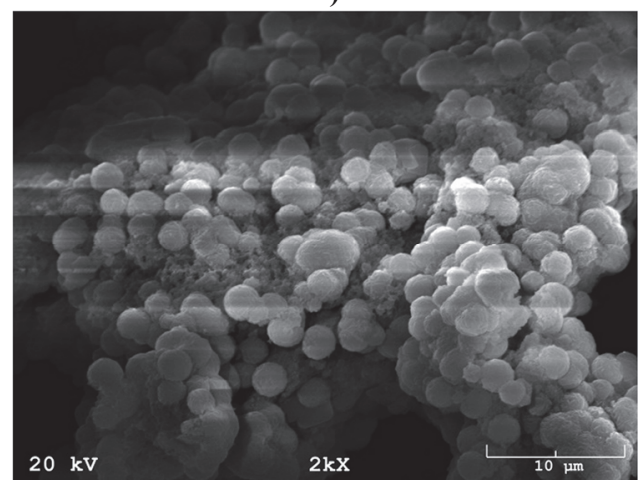


g)

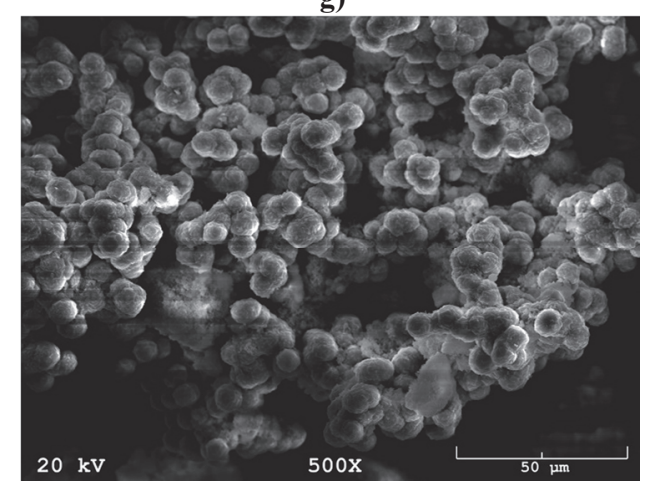

h)

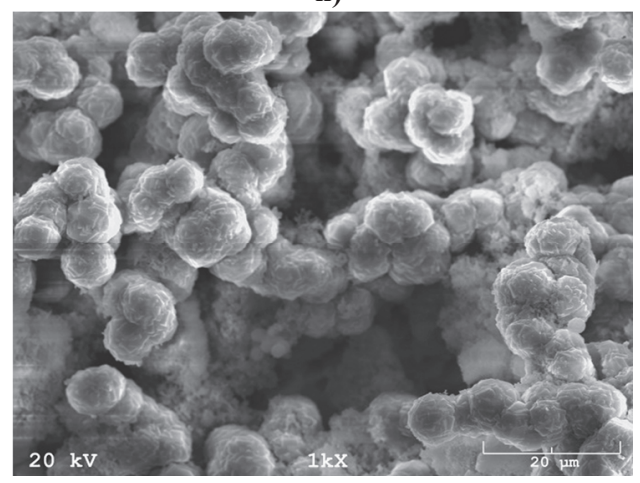

Fig. 7. SEM images of sample P1A (a, b); SEM images of sample P1H (c, d); SEM images of sample P2A (e, f); SEM images of sample P2H (g, h).

a)

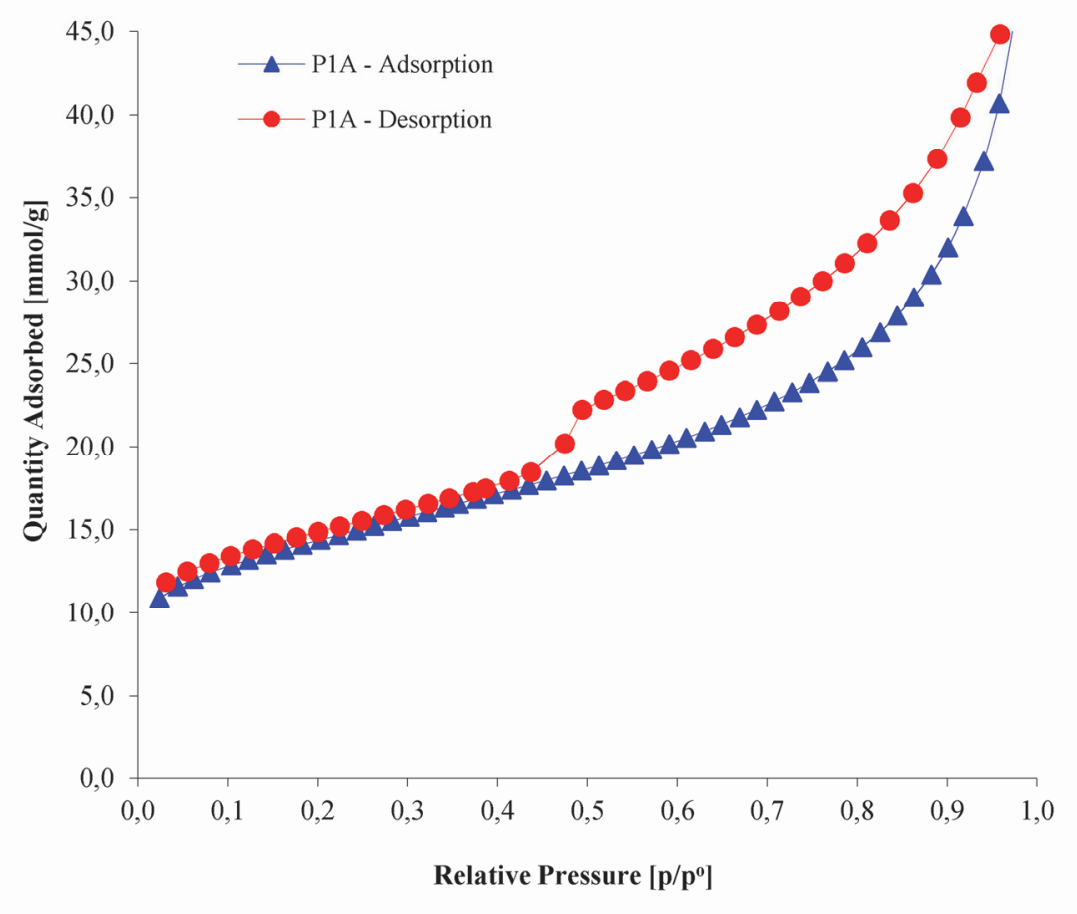


b)

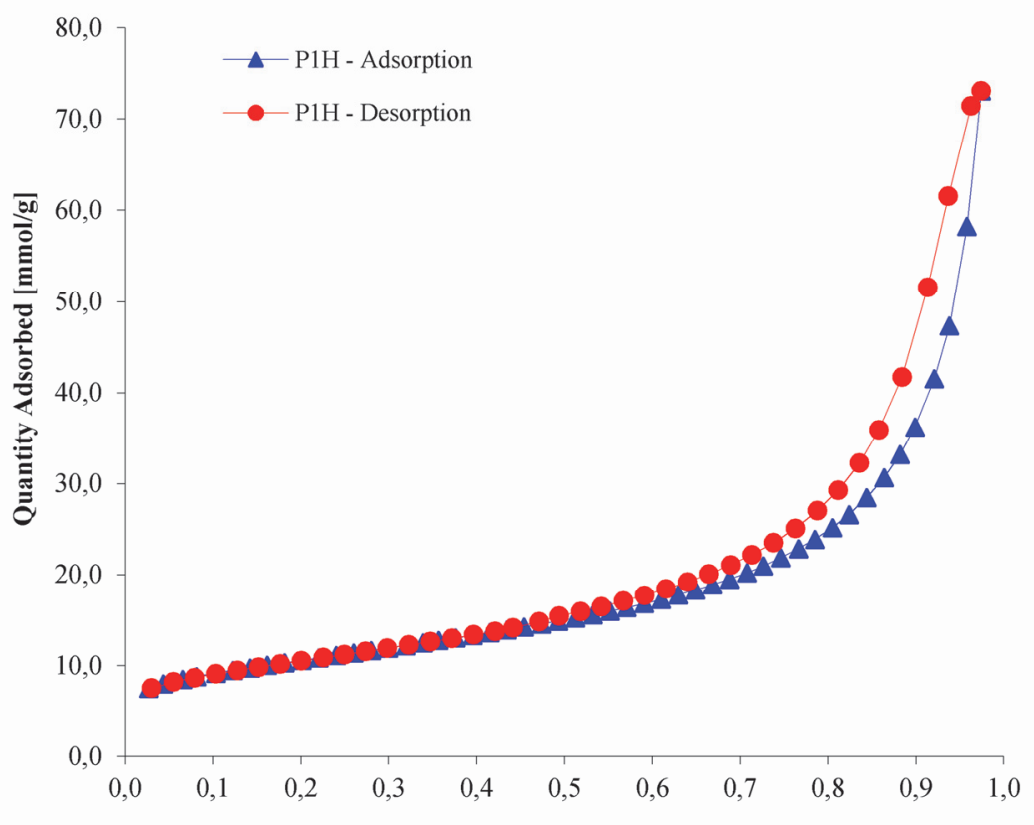

Relative Pressure $\left[\mathrm{p} / \mathbf{p}^{0}\right]$

c)

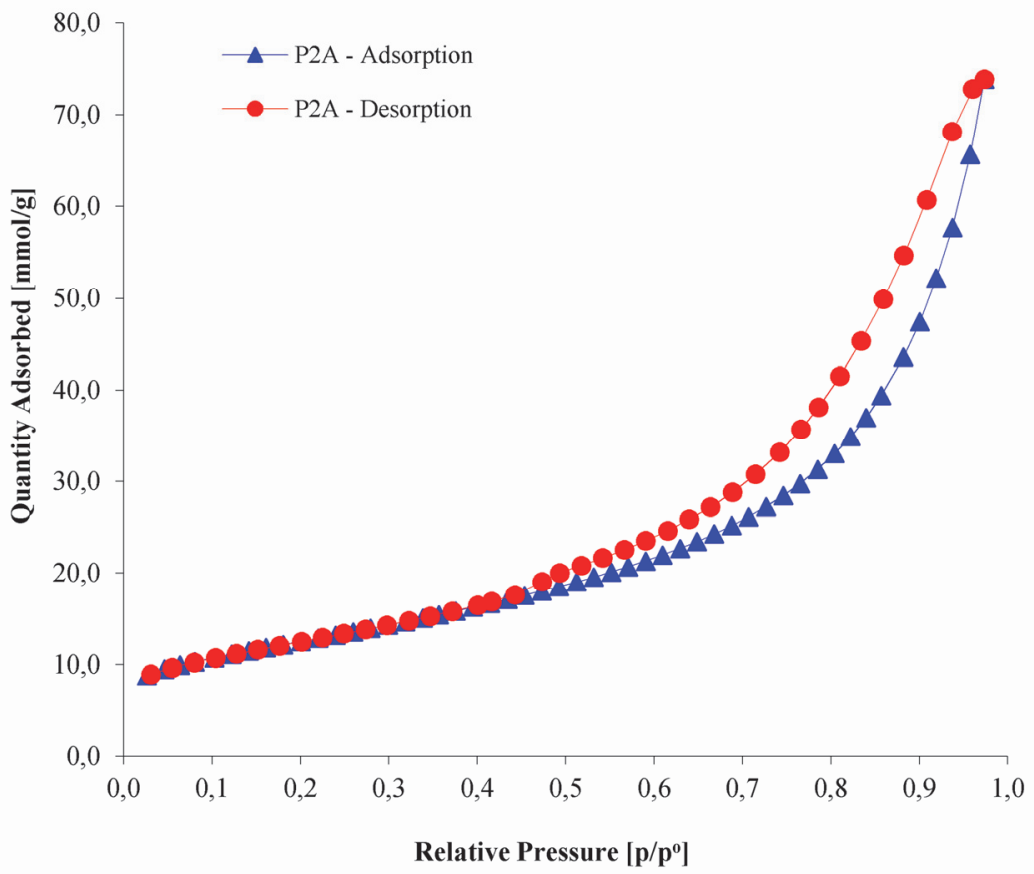


d)

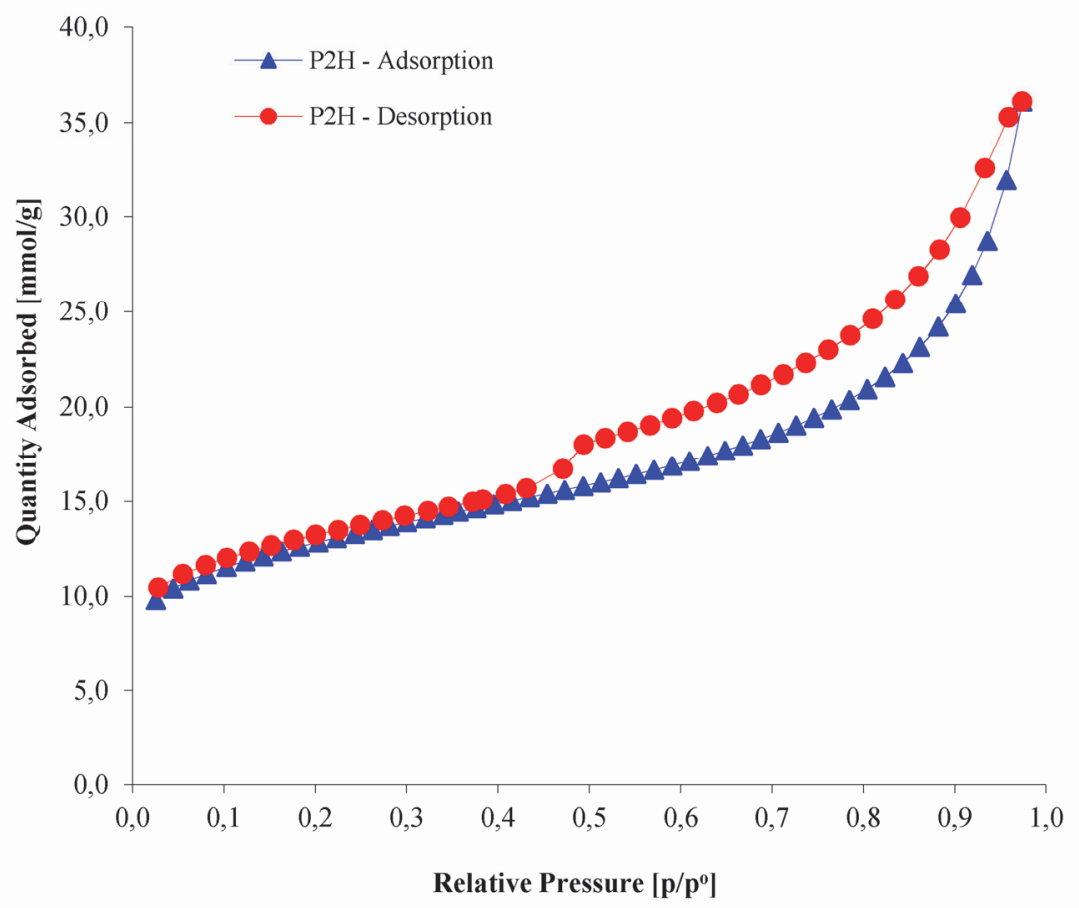

Fig. 8. BET adsorption and desorption isotherms: (a) P1A, (b) P1H, (c) P2A, (d) P2H.

Comparison of the CEC and AEC results for P1 and P1A (Table 4 and 5) as well as for $\mathrm{P} 2$ and $\mathrm{P} 2 \mathrm{~A}$ (Table 4 and 5) indicates that the process of autoclaving increased the cation exchange capacity of samples P1A and P2A. The cation exchange capacity of sample P1A increased three times compared to sample P1. For sample P2A, the CEC increased twenty times compared to sample P2. The AEC in both P1A and P2A samples (compared to samples P1 and P2) has not changed.

TABLE 5

Textural testing, CEC and AEC results for samples $\mathrm{P} 1 \mathrm{~A}, \mathrm{P} 1 \mathrm{H}, \mathrm{P} 2 \mathrm{~A}$ and $\mathrm{P} 2 \mathrm{H}$.

\begin{tabular}{|c|c|c|c|c|c|c|c|}
\hline Sample & $\begin{array}{l}\text { BET } \\
{\left[\mathrm{m}^{2} / \mathrm{g}\right]}\end{array}$ & $\begin{array}{l}\mathrm{BJH}^{1} \\
{\left[\mathrm{~m}^{2} / \mathrm{g}\right]}\end{array}$ & $\begin{array}{l}\text { Single point } \\
\text { adsorption }{ }^{2} \\
{\left[\mathrm{~cm}^{3} / \mathrm{g}\right]}\end{array}$ & $\begin{array}{l}\text { Adsorption } \\
\text { average }^{3} \\
{[\mathrm{~nm}]}\end{array}$ & $\begin{array}{l}\text { BJH } \\
\text { Adsorption }{ }^{4} \\
{[\mathrm{~nm}]}\end{array}$ & $\begin{array}{l}\text { CEC } \\
{[\mathrm{meq} / 100 \mathrm{~g}]}\end{array}$ & $\begin{array}{l}\text { AEC } \\
{[\mathrm{meq} / 100 \mathrm{~g}]}\end{array}$ \\
\hline P1A & 51.49 & 32.43 & 0.071 & 5.50 & 8.18 & 15.18 & 34.39 \\
\hline $\mathrm{P} 1 \mathrm{H}$ & 37.09 & 31.60 & 0.113 & 12.20 & 14.47 & - & - \\
\hline $\mathrm{P} 2 \mathrm{~A}$ & 43.30 & 39.38 & 0.114 & 10.60 & 11.85 & 61.39 & 24.80 \\
\hline $\mathrm{P} 2 \mathrm{H}$ & 46.26 & 26.76 & 0.056 & 4.80 & 7.61 & - & - \\
\hline
\end{tabular}




\section{Conclusions}

This article presents the results of a comprehensive study related to the reuse of hazardous incineration plant wastes. The results of the current investigation showed obtaining different types of zeolite structures, depending on the method of synthesis. Synthesis of the alkaline waste-codes 190112 and 190114 leads to morphological changes in these materials and the creation of such zeolite forms as chabazite and thomsonite (for waste-code 190112), and also analcime and thomsonite (for waste-code 190114). Chabazite and analcime can be valuable absorbents material, for example in gas filters, membranes, and industrial water treatment. As a result of the synthesis carried out in an autoclave it is possible to obtain materials which have a BET specific surface area of above $50 \mathrm{~m}^{2} \mathrm{~g}^{-1}$ (for waste-code 190112) and above $40 \mathrm{~m}^{2} \mathrm{~g}^{-1}$ (for waste-code 190114).

Acknowledgments. The authors would like to express their gratitude to the National Centre for Research and Development and the National Fund for Environmental Protection and Water Management for supporting this work with grant GEKON1/05/213240/35/2015.

\section{References}

Aiello, R., Giordano, G., \& Testa, F. (2002). Impact of zeolites and other porous materials on the new technologies at the beginning of the new millennium; Elsevier Science.

Armbruster, T., \& Gunter, M. E. (2001). Crystal structures of natural zeolites. In D.L. Bish \& D.W. Ming (Eds) Natural Zeolites: Occurrence, Properties, Applications. Washington, D.C., pp.1-67. Reviews in Mineralogy and Geochemistry.

Belviso, C., Cavalcante, F., \& Fiore, S. (2010). Synthesis of zeolite from Italian coal fly ash: Differences in crystallization temperature using sea water instead of distilled water. Waste Management, 30(5), 839-847. DOI: 10.1016/j.wasman.2009.11.015.

Chang, K. L., \& Shih, W. H. (1998). A general method for the conversion of fly ash into Zeolites as ion exchangers for cesium. Industrial \& Engineering Chemistry Research, 37(1), 71-78. DOI: 10.1021/ie970362o.

Charles, H. K. Lam, Alvin, W. M. Ip., Barford, J. P., \& McKay, G. (2010). Use of Incineration MSW Ash: A Review. Sustainability, 2, 1943-1968. DOI:10.3390/su2071943.

Chiang, Y. W., Ghyselbrecht K., Santos, R. M., Meesschaert, B., \& Martens, J. A. (2012). Synthesis of zeolitictype adsorbent material from municipal solid waste incinerator bottom ash and its application in heavy metal adsorption. Catalysis Today, 190(1), 23-30. DOI: 10.1016/j.cattod.2011.11.002.

Chica, A. (2013). Zeolites: Promised Materials for the Sustainable Production of Hydrogen. ISRN Chemical Engineering, DOI: 10.1155/2013/907425.

Derkowski, A., Franus, W., Beran, E., \& Czimerova, A. (2006). Properties and potential applications of zeolitic materials produced from fly ash using simple method of synthesis. Powder Technology, 166, 47-54. DOI: 10.1016/j.powtec.2006.05.004.

Fotovat, F., Kazemian, H., \& Kazemeini, M. (2009). Synthesis of Na-A and faujasitic zeolites from high silicon fly ash. Materials Research Bulletin, 44(2), 913-917. DOI: 10.1016/j.materresbull.2008.08.008.

Franus, W., Wdowin, M., \& Franus, M. (2014). Synthesis and characterization of zeolites prepared from industrial fly ash. Environmental Monitoring and Assessment, 186, 5721-5729. DOI: 10.1007/s10661-014-3815-5.

Grela, A., Łach, M., Mikuła, J., \& Hebda, M. (2016 a). Thermal analysis of the products of alkali activation of fly ash from CFB boilers. Journal of Thermal Analysis and Calorimetry, 123(2), 1609-1621. DOI: 10.1007/s10973-016-5257-5.

Grela, A., Hebda, M., Łach, M., \& Mikuła, J. (2016 b). Thermal behavior and physical characteristics of synthetic zeolite from CFB-coal fly ash. Microporous and Mesoporous Materials, 220, 155-162. DOI: 110.1016/j.micromeso.2015.08.036.

Grela, A., \& Bajda, T., (2017). Usuwanie wybranych związków biogennych z roztworów wodnych z wykorzystaniem metakaolniu i zmodyfikowanego metakaolinu. Inżynieria Ekologiczna, 18(2), 30-38. DOI: $10.12912 / 23920629 / 68339$ 
Gupta, V. K., Ali, I., Saini, V.K, Van Gerven. T., Van Bruggen, B. D., \& Vandecasteele, C. (2005). Removal of dyes from wastewater using bottom ash. Industrial \& Engineering Chemistry Research, 44(10), 3655-3664. DOI: $10.1021 / \mathrm{ie} 0500220$.

Hollman, G. C., Steenbruggen, G., \& Janssen-Jurkovicova, M. (1999). A two step process for the synthesis of zeolites from coal fly ash. Fuel, 78 (10), 1225-123. DOI: 10.1016/S0016-2361(99)00030-7.

Inada, M., Eguchi, Y., Enomoto, N., \& Hojo, J. (2005). Synthesis of zeolite from coal fly ashes with different silica-alumina composition. Fuel, 84 (2-3), 299-304. DOI: 10.1016/j.fuel.2004.08.012.

Łach, M., Mikuła, J., \& Hebda, M. (2016). Thermal analysis of the by-products of waste combustion. Journal of Thermal Analysis and Calorimetry, 125(3), 1035-1045. DOI: 10.1007/s10973-016-5512-9.

Łącka-Matusiewicz, M., \&Fraś, K. (2012), Wpływ zagospodarowania ubocznych produktów spalania węgla na redukcję emisji $\mathrm{CO}_{2}$ do środowiska [w:] Popioły z energetyki. XI Międzynarodowa Konferencja pt. „Popioły z Energetyki". (red.) Szczygielski T., 19, 131-150.

Miyake, M., Tamura, Ch., \& Matsuda, M. (2002). Resource Recovery of Waste Incineration Fly Ash: Synthesis of Zeolites A and P. Journal of the American Ceramic Society, 85(7), 1873-75. DOI: 10.1111/j.11512916.2002.tb00368.x.

Morency, J. R., Panagiotou, T., \& Senior, C. L. (2002). Zeolite sorbent that effectively removes mercury from flue gases. Filtration \& Separation, 39(7), 24-26. DOI: 10.1016/S0015-1882(02)80207-5.

Pająk, T. (1996). Dioksyny w procesie spalania odpadów komunalnych - zagrożenia, normy, aktualna sytuacja, przeciwdziałanie. Rocznik Państwoweg Zakładu Higieny,47(1), 105-119.

Querol, X., Alastuey, A., Fernandez-Turiel, J. L., \& Lopez-Soler, A. Synthesis of zeolites by alcaline activation of ferro-aluminous fly ash. Fuel, 74(8), 1226-1231.

Rodziewicz, J., Mielcarek, A., Kłodowska, I., Janczukowicz, W., Choińska-Żurek, E., \& Wolter A. (2016). Usuwanie fosforu na filtrach $\mathrm{z}$ wypełnieniem $\mathrm{z}$ granulatu $\mathrm{z}$ popiołów ze spalania osadów ściekowych. Inżynieria Ekologiczna, 48, 186-190. DOI: 10.12912/23920629/63273.

Sallam, M., Carnahan, R. P., Zayed, A., \& Sunol, S. (2008). Recycling of Municipal Solid Waste Ash through an Innovative Technology to Produce Commercial Zeolite material of High Cation Exchange Capacity, Proceedings of NAWTEC16 16th Annual North American Waste-to-Energy Conference May 19-21, 2008, Philadelphia, Pennsylvania, USA. DOI: 10.1115/NAWTEC16-1919.

Shim, Y. S., Kim, Y. K., Kong, S. H., Rhee, S. W., \& Lee, W. K. (2003). The adsorption characteristics of heavy metals by various particle sizes of MSWI bottom ash. Waste Management, 23(9), 851-857. DOI: 10.1016/S0956-053X(02)00163-0.

Tamura, Ch., Matsuda, M., \& Miyake, M. (2006). Conversion of Waste Incineration Fly Ash into Zeolite A and Zeolite P by Hydrothermal Treatment. Journal of the Ceramic Society of Japan, 114(2), 205-209. DOI: 10.2109 /jcersj.114.205.

Tao, Y., Kanoh, H., Abrams, L., \& Kaneko, K. (2006). Mesopore-modified zeolites: Preparation, characterization, and applications. Chemical Reviews, 106(3), 896-910. DOI: 10.1021/cr040204o.

Wdowin, M., Franus, W., \& Panek, R. (2012). Preliminary results of usage possibilities of carbonate and zeolitic sorbents in $\mathrm{CO}_{2}$ capture. Fresenius Environmental Bulletin, 21(12), 3726-3734.

Wdowin, M., Wiatros-Motyka, M., Panek, R., Stevens L. A., Franus W., \& Snape C. E. (2014). Experimental study of mercury removal from exhaust gases. Fuel, 128, 451-457. DOI: 10.1016/j.fuel.2014.03.041.

Wielgosiński, G., \& Naniecińska, O. (2016). Spalanie odpadów komunalnych - perspektywa roku 2020. Nowa Energia, 2, 1-15.

Yang, G. C., \& Yang, T. Y. (1998). Synthesis of zeolites from municipal incinerator fly ash. Journal of Hazardous Materials, 62, 75-89. DOI: 10.1016/S0304-3894(98)00163-0. 